\title{
Evaluation of Radiological Parameters in Elderly Patients Treated Conservatively for Distal Radius Fracture
}

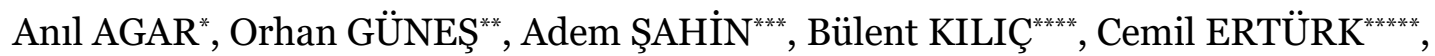 \\ Deniz GÜLABİ******
}

\begin{abstract}
Aim: Distal radius fractures are one of the most common fractures in the elderly population. In this study, we aimed to evaluate the changes in radiological parameters in patients treated conservatively for distal radius fractures according to fracture types and age groups.

Methods: Patients who received conservative treatment for distal radius fractures between 10 January 2015 and January 2019 were retrospectively screened. Fractures of the patients were divided according to the Arbeitsgemeinschaft für Osteosynthesefragen (AO) classification, and the patients were divided into two groups as under 75 years old and over 75 years old. Ulnar variance, radial inclination, and volar tilt values of the patients after fracture reduction and at the end of the treatment were examined and compared with each other.
\end{abstract}

Results: Wrist radiographs of 232 patients were evaluated in the study. According to the AO classification, 151 patients had type A (A2:144, A3:7), 46 patients had type B (B1:6, B2:33, B3:7), and 35 patients had type $\mathrm{C}\left(\mathrm{C}_{1}: 21, \mathrm{C}_{2}: 10, \mathrm{C}_{3}: 4\right)$ fractures. While there were 134 patients in the group under 75 years old, there were 98 patients in the patient group over 75 years old. Radiological parameters (except volar tilt in AO type C fractures) were found to be impaired according to the initial evaluation after treatment, regardless of the fracture type and age.

Conclusion: It should be kept in mind that patients treated conservatively for distal radius fractures may impair the reduction quality of the patients, the accepted radiological parameters may deteriorate. In elderly

\footnotetext{
Özgün Araştırma Makalesi (Original Research Article)

Geliş / Received: 30.09.2021 \& Kabul / Accepted: 08.12.2021

DOI: https://doi.org/10.38079/igusabder.1003090

* M.D., Consultant Orthopaedic Surgeon, University of Health Sciences, Kanuni Sultan Suleyman Training and Research Hospital, Orthopaedic and Traumatology Department, Istanbul, Turkey, E-mail: dr.anilagar@hotmail.com ORCID https://orcid.org/o000-0003-2344-7801

${ }^{* *}$ M.D., Consultant Orthopaedic Surgeon Assistant, University of Health Sciences, Kanuni Sultan Suleyman Training and Research Hospital, Orthopaedic and Traumatology Department, Istanbul, Turkey,

E-mail: gunesorhann@gmail.com ORCID https://orcid.org/oooo-0001-6166-1118

${ }_{* * * *}$ M.D., Consultant Orthopaedic Surgeon, University of Health Sciences, Kanuni Sultan Suleyman Training and Research Hospital, Orthopaedic and Traumatology Department, Istanbul, Turkey, E-mail: ademtito@yahoo.com ORCID https://orcid.org/0000-0002-4020-9488

${ }_{* * * *}$ Consultant Orthopaedic Surgeon, University of Health Sciences, Kanuni Sultan Suleyman Training and Research Hospital, Orthopaedic and Traumatology Department, Istanbul, Turkey, E-mail: drbulentk@hotmail.com ORCID https://orcid.org/oooo-0001-8101-804X

***** M.D., Assoc. Prof., Consultant Orthopaedic Surgeon, University of Health Sciences, Kanuni Sultan Suleyman Training and Research Hospital, Orthopaedic and Traumatology Department, Istanbul, Turkey,

E-mail: erturkc@yahoo.com ORCID https://orcid.org/o000-0002-9225-917X

****** M.D., Assoc. Prof., Consultant Orthopaedic Surgeon, University of Health Sciences, Kanuni Sultan Suleyman Training and Research Hospital, Orthopaedic and Traumatology Department, Istanbul, Turkey,

E-mail:dgulabi@yahoo.com ORCID https://orcid.org/oooo-0002-4131-7536
}

ETHICAL STATEMENT: Patients treated for DRF at Level-1 tertiary trauma hospital between January 2015 and January 2019 were analysed retrospectively. The study was approved by the Medical Research Ethics Committee of the same hospital. 
patients, the deterioration in these parameters was independent of gender, the presence of ulnar fractures, and fracture classification.

Keywords: Fracture, distal radius, elderly, conservative treatment.

\section{Distal Radius Kırı̆̆ı Nedeniyle Konservatif Tedavi Edilen Yaşlı Hastalarda Radyolojik Parametrelerin Değerlendirilmesi}

\section{$\ddot{O} \mathbf{z}$}

Amaç: Radius distal kırıkları yaşlı popülasyonda en sık görülen kırıklardan biridir. Bu çalışmada, radius distal kırıkları nedeniyle konservatif tedavi edilen hastalarda radyolojik parametrelerdeki değişiklikleri kırık tiplerine ve yaş gruplarına göre değerlendirmeyi amaçladık.

Yöntem: 10 Ocak 2015 ile Ocak 2019 tarihleri arasında distal radius kırı̆g nedeniyle konservatif tedavi alan hastalar geriye dönük olarak tarandı. Hastaların kırıkları Arbeitsgemeinschaft für Osteosynthesefragen (AO) sınıflamasına göre gruplandı ve hastalar 75 yaş altı ve 75 yaş üstü olarak iki gruba ayrıldı. Hastaların kırık redüksiyonu sonrası ve tedavi sonundaki ulnar varyans, radyal eğim ve volar tilt değerleri incelenerek birbirleriyle karşlaştırıldı.

Bulgular: Çalışmada 232 hastanın el bileği radyografileri değerlendirildi. AO sınıflamasına göre 151 hastada tip A (A2:144, A3:7), 46 hastada tip B (B1:6, B2:33, B3:7) ve 35 hastada tip C (C1:21, C2:10, C3:4) kırıklar vardı. 75 yaş altı grupta 134 hasta varken, 75 yaş üstü hasta grubunda 98 hasta vardı. Radyolojik parametreler (AO tip C kırıklarda volar tilt hariç) tedavi sonrası ilk değerlendirmeye göre kırık tipi ve yaştan bağımsız olarak bozuldu.

Sonuç: Radius distal kırıkları nedeniyle konservatif tedavi edilen hastaların redüksiyon kalitesinin bozulabileceği, kabul edilen radyolojik parametrelerin kötüleşebileceği akılda tutulmalıdır. Yaşlı hastalarda bu parametrelerdeki bozulma cinsiyet, ulnar kırık varlığı ve kırık sınıflandırmasından bağımsızdır.

Anahtar Sözcükler: Kırık, distal radius, yaşlı, konservatif tedavi.

\section{Introduction}

The distal radius fracture (DRF) is the second most common fracture in the elderly population. It has a bimodal distribution with a peak incidence in people 18-25 years of age and the second peak in people older than $65^{1}$. They constitute $8-15 \%$ of all fractures ${ }^{2}$. The fractures occur as a result of low-energy trauma in elderly patients. Approximately $15 \%$ of female patients over 65 years old experience a DRF once in their remaining lifetimes.

There are surgical and non-surgical treatment methods for treating DRFs, including closed reduction and plastering, fixation with K-wire, external fixation, and open reduction and internal fixation ${ }^{4-10}$. However, conservative treatment practices are more prevalent in the elderly patient population due to comorbid diseases ${ }^{11,12}$. Several researchers have suggested that elderly patients should be treated conservatively, even in the context of an unstable fracture pattern, because, in contrast to younger patients, fracture reduction quality is not associated with functional outcome in this age group ${ }^{13,14}$. In selecting a treatment method, factors such as the patient's age, lifestyle, accompanying health problems, treatment compliance, and physical and mental capacity should be considered along with the type of fracture ${ }^{15,16}$. Although various treatment methods and fixing materials have been described in the treatment of unstable fractures, a standard treatment method has not been established ${ }^{17}$. Whichever method is chosen, the primary condition to be achieved is to optimise ulnar variance (UV), radial inclination (RI) and volar tilt (VT) to the anatomical repair of the distal radial joint face ${ }^{18-20}$. Nevertheless, functional results have been good, despite the deformity in fractures in low-demand patients5,10. 
Older age groups were likely to be treated more conservatively than surgical intervention. The primary problem with conservative treatment in the older age group is the loss of reduction due to osteoporosis and the resulting deterioration of radiological parameters ${ }^{21}$. This study aimed to evaluate the loss of reduction by measuring changes in radiological parameters (UV, RI, VT). Measurements were made according to fracture type, gender, accompanying ulnar fracture, and elderly patients with distal radial fractures treated conservatively.

\section{Material and Methods}

Patients treated for DRF at Level-1 tertiary trauma hospital between January 2015 and January 2019 were analysed retrospectively. The study was approved by the Medical Research Ethics Committee of the same hospital. Patients over 65 years old with distal radius fractures and treated conservatively were included in the study. Patients under 65, patients with open fractures, patients treated surgically, patients with inadequate follow-up, and patients whose plaster treatment was terminated due to circulatory problems were excluded from the study. Patients who underwent a secondary manipulation at any stage following their initial consultation or those who underwent a second surgical intervention were also excluded from the study. The patients' age, gender, AO (Arbeitsgemeinschaft für Osteosynthesefragen) fracture classification, any accompanying ulnar fracture, UV, RI and VT values after plaster application were reviewed on the 10th day and at 60 days after injury (Figures 1, 2 and 3 show sample cases according to the AO classification).

Figure 1. Anteroposterior and lateral radiographs of a 79-year-old female patient with AO A2 type fracture at the time of admission, at the 1oth day and at the 2nd month control

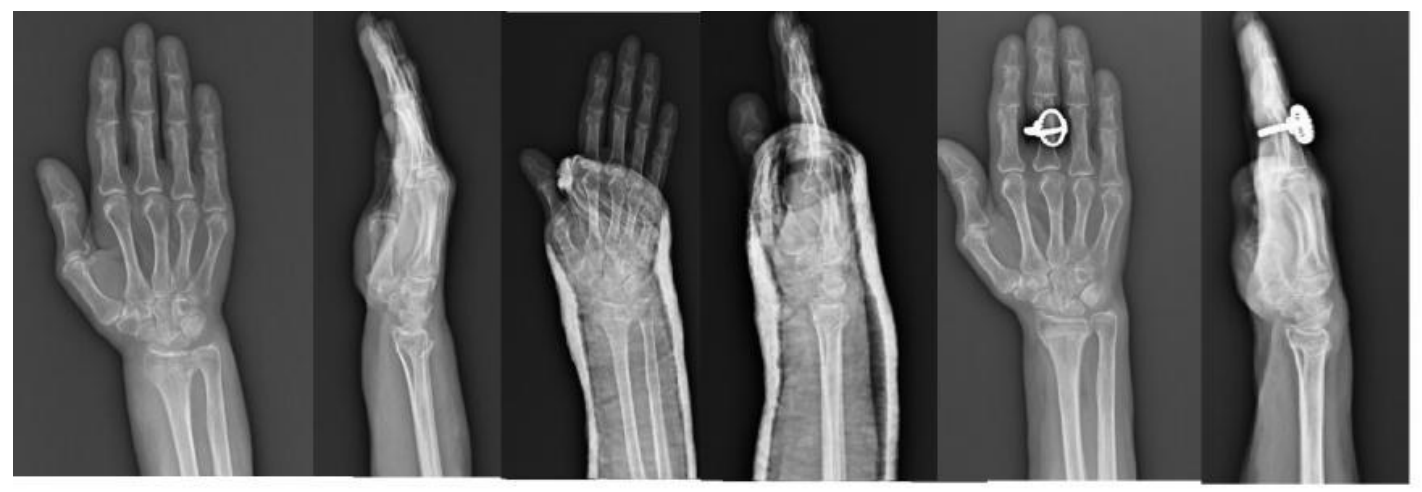

Figure 2. Anteroposterior and lateral radiographs of a 81-year-old female patient with AO B3 type fracture at the time of admission, at the 1oth day and at the 2nd month control

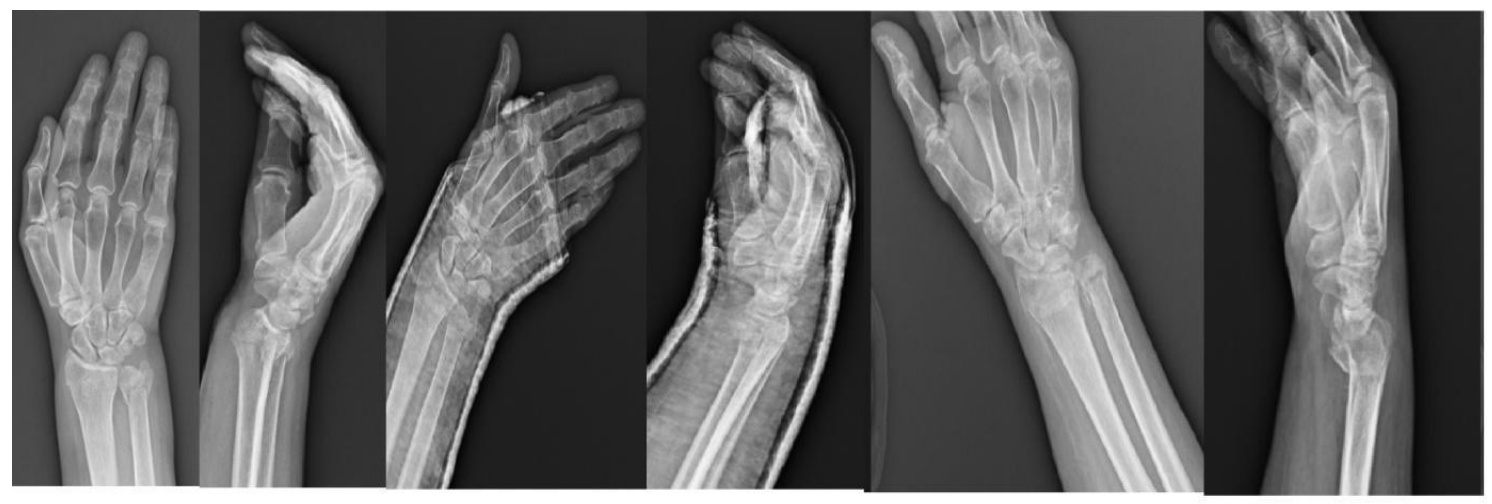


Figure 3. Anteroposterior and lateral radiographs of a 85-year-old female patient with AO C1 type fracture at the time of admission, at the 1oth day and at the 2nd month control

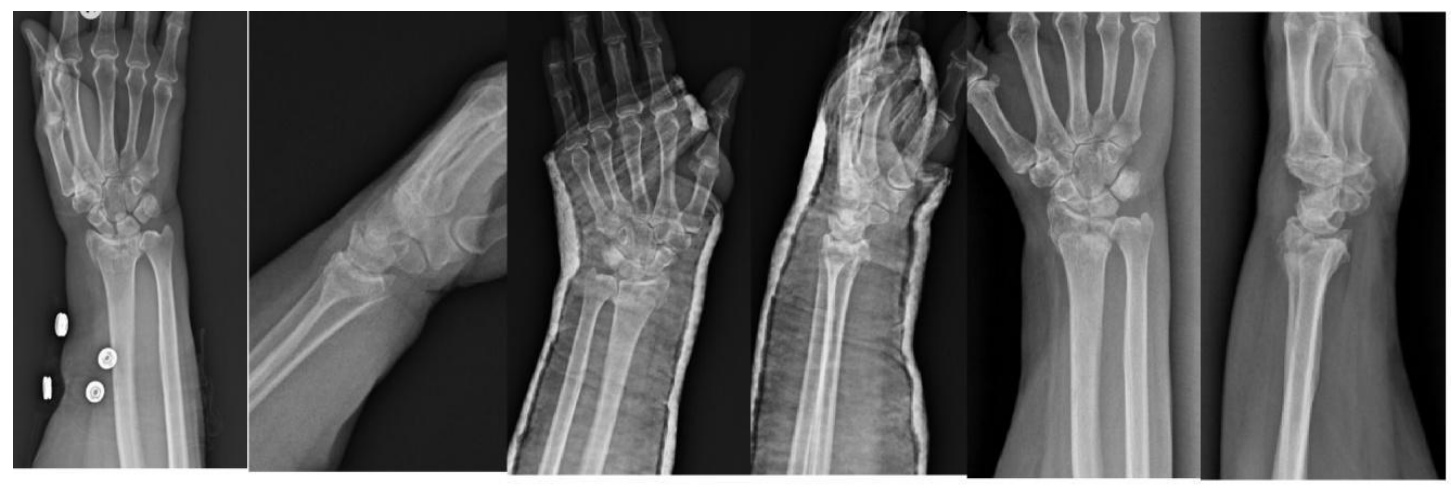

When the patients applied to the emergency room, their fractures were evaluated using a radiograph. Afterwards, the fracture was reduced by an orthopaedic specialist with at least five years of experience and an accompanying orthopaedic surgery resident. A short arm circular cast was applied under sedation. The position of the cast immobilisation was the wrist fixed at flexion of $30^{\circ}$, ulnar deviation of $10^{\circ}$ and pronation of 60 (In B3 type fractures, the wrist was not flexed and cast in the neutral or minimal extension position).

After the plaster cast was formed, a control radiograph was taken. The patients were informed about compartment syndrome and other complications with plaster cast treatment; the patients were then discharged with recommending elevation. The patients were evaluated in the orthopaedic outpatient clinic for circulation follow-up in the first three days. Plaster treatment was discontinued in patients with circulatory problems or signs of plaster pressure. On the tenth day, radiography was performed on patients who continued to be treated with a cast. Plaster treatment was terminated on the fourth week on average, and the patients were checked for radiography 30 days after treatment. Because early mobilisation positively affects functional results in distal radius fractures in elderly patients, conservative treatment was discontinued in our clinic at an average of four weeks ${ }^{21,22}$. Patients were trained about isotonic and isometric exercises for wrist, fingers and elbow. In addition, patients who were deemed necessary were referred for physical therapy after the treatment. Radiological observations of the patients were evaluated at the time of closed reduction and plaster cast application on the 1oth day and 60 days after the injury.

The patients' UV, RI and VT values were measured at the beginning of the treatment, the tenth day, and after treatment by an orthopaedic resident blinded from the study. In addition, fractures in the type A group according to the $\mathrm{AO}$ classification were evaluated according to the presence of instability criteria described by Lafontaine et al. ${ }^{23}$.

Typically, "elderly" has been defined as 65 years old or older, while those 65 through 74 years are referred to as "early elderly;" those over 75 years old are termed "late elderly" 24 . The patients were divided into two groups, under 75 and over 75, and the progression in UV, RI and VT values between age groups were evaluated. In addition, based on the AO classification, the change in these values was also monitored.

\section{Statistical Evaluation}

When evaluating the findings obtained in the study, IBM SPSS Statistics 22 for statistical analysis (SPSS IBM, Turkey) programs were used. While evaluating the study data, the suitability of the 
parameters to the normal distribution was evaluated with the Shapiro Wilks test. While evaluating the study data, descriptive statistical methods (mean, standard deviation, frequency) as well as the One-way Anova test was used to compare normally distributed parameters between groups in comparison of quantitative data. Kruskal Wallis test was used for intergroup comparisons of parameters that did not show normal distribution, and Dunn's test was used to determine the group that caused the difference. Student's t-test was used for comparisons of parameters showing normal distribution between two groups, and Mann Whitney U test was used for comparisons of parameters not showing normal distribution between two groups. In the intergroup comparisons of normally distributed parameters, analysis of variance with Repetitive Measurements and Bonferroni test was used to determine the period that caused the difference. Friedman test was used for intra-group comparisons of parameters that did not show normal distribution, and Wilcoxon sign test was used to determine the period that caused the difference. Significance was evaluated at the $\mathrm{p}<0.05$ level.

\section{Results}

In the study, 660 patients were followed conservatively between January 2015 and January 2019. Of those, 232 patients met the inclusion criteria for the study. Of the 232 patients, 44 (19\%) were male, and $188(81 \%)$ were female. The patients varied in age from 65 to 105 , with a mean age of $74.93 \pm 7.91$ years; 134 patients in the group were under 75 years old (57.8\%), and 98 patients over 75 years old (42.2\%). According to the AO classification of fractures, 151 patients had type A (A2:144, A3:7), 46 patients had type B (B1:6, B2:33, B3:7), and 35 patients had type C (C1:21, C2:10, C3:4).

There was no difference in radiological parameters between patients under 75 years old and those over 75 years old (table 1). As a result of the paired comparisons made to determine the period of the difference between the initial, 10th day and 2nd month radiological parameter levels values, the RI change level between the 10th day and the 2nd month in both groups; the change in VT between the first and the 10th days for the group over 75 years was not statistically significant. All other changes were statistically significant (Table 1).

Table 1. Evaluation of radiological parameters according to age groups

\begin{tabular}{|c|c|c|c|c|}
\hline & & \multicolumn{2}{|l|}{ Age group } & \multirow{3}{*}{$\mathbf{p}^{\mathbf{1}}$} \\
\hline & & $<75$ year & $\geq 75$ year & \\
\hline & & Mean \pm SD & $\operatorname{Mean} \pm$ SD & \\
\hline \multirow[t]{7}{*}{$\mathbf{R I}$} & Beginning & $23,05 \pm 4,49$ & $21,38 \pm 5,4$ & ${ }^{1 \mathrm{1a}} \mathbf{0 , 0 1 1 ^ { * }}$ \\
\hline & 10. day & $20,68 \pm 5,59$ & $19,86 \pm 6,6$ & ${ }^{1 \mathrm{a}} \mathbf{0 , 3 1 1}$ \\
\hline & 2. month & $20,26 \pm 5,33$ & $19,13 \pm 7,12$ & ${ }^{1 a} \mathbf{0 , 1 9 0}$ \\
\hline & $\mathbf{p}^{\mathbf{2 a}}$ & $\mathbf{0 , 0 0 0 *}$ & $\mathbf{o , o o 3}^{*}$ & \\
\hline & Beginning-1o.day $p^{3 a}$ & $O, O O O^{*}$ & $0,012^{*}$ & \\
\hline & Beginning-2.month $p^{3 a}$ & $O, O O O^{*}$ & $0,004^{*}$ & \\
\hline & 1o.day-2.month $p^{3 a}$ & 0,762 & 0,570 & \\
\hline \multirow[t]{6}{*}{ UV (median) } & Beginning & $1,28 \pm 2,3(1,3)$ & $2,11 \pm 2,61(2)$ & ${ }^{16} \mathbf{0}, \mathbf{0 3 1}{ }^{*}$ \\
\hline & 10. day & $2,29 \pm 2,22(2,6)$ & $2,92 \pm 2,83(2,7)$ & ${ }^{1 b} \mathbf{0 , 1 6 7}$ \\
\hline & 2. month & $2,75 \pm 2,16(2,9)$ & $3,42 \pm 2,98(3,6)$ & 1bo,117 \\
\hline & $\mathbf{p}^{\mathbf{2 b}}$ & o,ooo* & o,ooo* & \\
\hline & Beginning-1o.day $p^{3 a}$ & $O, O O O^{*}$ & $O, O O O^{*}$ & \\
\hline & Beginning-2.month $p^{3 a}$ & $0,000^{*}$ & $O, O O O^{*}$ & \\
\hline
\end{tabular}




\begin{tabular}{|c|c|c|c|c|}
\hline & 10.day-2.month $p^{3 a}$ & $O, O O O^{*}$ & $0,003^{*}$ & \\
\hline \multirow[t]{7}{*}{ VT } & Beginning & $4,72 \pm 9,68$ & $4,08 \pm 9,94$ & ${ }^{12} \mathbf{0 , 6 2 7}$ \\
\hline & 10. day & $1,71 \pm 10,52$ & $2,92 \pm 13,71$ & ${ }^{12} \mathbf{0}, 451$ \\
\hline & 2. month & $-0,24 \pm 12,16$ & $0,91 \pm 14,76$ & ${ }^{12} \mathbf{0 , 5 1 7}$ \\
\hline & $\mathbf{p}^{\mathbf{2 a}}$ & o,o00* & $\mathbf{0 , 0 1 0 *}$ & \\
\hline & Beginning-1o.day $p^{3 a}$ & $O, O O O^{*}$ & 0,607 & \\
\hline & Beginning-2.month $p^{3 a}$ & $O, O O O^{*}$ & $0,012^{*}$ & \\
\hline & 10.day-2.month $p^{3 a}$ & $0,003^{*}$ & $0,04 O^{*}$ & \\
\hline
\end{tabular}

${ }^{1 a}$ Student $t$ Test ${ }^{1 b}$ Mann Whitney $U$ Test ${ }^{2 a}$ Analysis of Variance in Repetitive Measurements ${ }^{2 b}$ Friedman Test ${ }^{3 a}$ Bonferroni Test $\quad{ }^{3 b}$ Wilcoxon Sign Test ${ }^{*} p<0.05$

When the patients were grouped according to their gender, the initial 1oth day and 2nd month RI values for men were significantly higher than the women, and there was no significant change in the RI value in male patients (Table 2).

There was no statistically significant difference in UV and VT values between the groups. As a result of the paired comparisons for women to determine when the difference in radiological parameters began, there was no significant difference between the 1oth day and the 2nd month RI. For men, the VT changed between the initial 10th day and the 2nd month. All other changes were statistically significant (Table 2).

Table 2. Evaluation of radiological parameters according to gender

\begin{tabular}{|c|c|c|c|c|}
\hline & & \multicolumn{2}{|l|}{ Gender } & \multirow{3}{*}{$\mathbf{p}^{\mathbf{1}}$} \\
\hline & & \multirow{2}{*}{$\begin{array}{l}\text { Male } \\
\text { Mean } \pm \text { SD }\end{array}$} & \multirow{2}{*}{$\begin{array}{l}\text { Female } \\
\text { Mean } \pm \text { SD }\end{array}$} & \\
\hline & & & & \\
\hline \multirow[t]{7}{*}{$\mathbf{R I}$} & Beginning & $24,27 \pm 4,63$ & $21,89 \pm 4,93$ & ${ }^{1 \mathrm{a}} \mathrm{O}, 004^{*}$ \\
\hline & 10. day & $23,92 \pm 4,89$ & $19,49 \pm 5,99$ & ${ }^{1 a} \mathbf{0 , 0 0 0} *$ \\
\hline & 2. month & $23,33 \pm 5,34$ & $18,96 \pm 6,06$ & ${ }^{1 \mathrm{a}} \mathrm{O}, 000^{*}$ \\
\hline & $\mathbf{p}^{\mathbf{2 a}}$ & $\mathbf{0 , 3 7 4}$ & о,000* & \\
\hline & Beginning-10.day $p^{3 a}$ & - & $O, O O O^{*}$ & \\
\hline & Beginning-2.month $p^{3 a}$ & - & $O, O 00^{*}$ & \\
\hline & 1o.day-2.month $p^{3 a}$ & - & 0,377 & \\
\hline \multirow[t]{7}{*}{ UV (median) } & Beginning & $1,41 \pm 2,76(1,5)$ & $1,68 \pm 2,39(1,6)$ & ${ }^{1 b} 0,481$ \\
\hline & 10. day & $2,11 \pm 2,37(2,2)$ & $2,67 \pm 2,54(2,7)$ & ${ }^{16} \mathbf{0 , 1 9 8}$ \\
\hline & 2. month & $2,82 \pm 2,43(3,2)$ & $3,08 \pm 2,59(2,9)$ & $1 \mathrm{~b} 0,650$ \\
\hline & $\mathbf{p}^{\mathbf{2 b}}$ & $\mathbf{o , o o o}^{*}$ & o,ooo* & \\
\hline & Beginning-1o.day $p^{3 a}$ & $O, O O O^{*}$ & $O, O O O^{*}$ & \\
\hline & Beginning-2.month $p^{3 a}$ & $0,000^{*}$ & $O, O 00^{*}$ & \\
\hline & 1o.day-2.month $p^{3 a}$ & $O, O O O^{*}$ & $O, O O O^{*}$ & \\
\hline \multirow[t]{3}{*}{ VT } & Beginning & $2,83 \pm 9,5$ & $4,83 \pm 9,82$ & ${ }^{1 a} 0,224$ \\
\hline & 1o. day & $0,7 \pm 10,39$ & $2,58 \pm 12,31$ & ${ }^{1 a} \mathbf{0 , 3 5 0}$ \\
\hline & 2. month & $-1,78 \pm 12,19$ & $0,72 \pm 13,54$ & ${ }^{1 a} \mathbf{0 , 2 6 3}$ \\
\hline
\end{tabular}




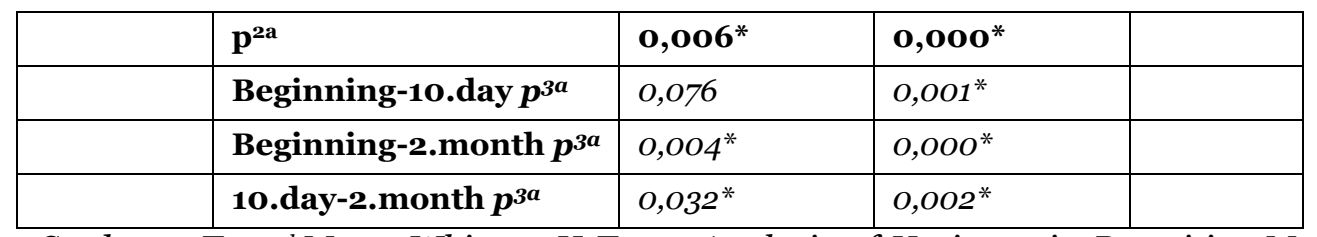

${ }^{1 a}$ Student $t$ Test ${ }^{1 b}$ Mann Whitney U Test ${ }^{2 a}$ Analysis of Variance in Repetitive Measurements ${ }^{2 b}$ Friedman Test ${ }^{3 a}$ Bonferroni Test $\quad{ }^{3 b}$ Wilcoxon Sign Test ${ }^{*} p<0.05$

When patients were grouped based on the presence or absence of an ulnar fracture accompanying a DRF, there was no difference in radiological parameters between groups (Table 3).

Table 3. Evaluation of radiological parameters according to accompanying ulnar fracture

\begin{tabular}{|c|c|c|c|c|}
\hline & & \multicolumn{2}{|c|}{ Accompanying Ulnar Fracture } & \multirow{3}{*}{$\mathbf{p}^{\mathbf{1}}$} \\
\hline & & \multirow{2}{*}{$\begin{array}{l}\text { Yes } \\
\text { Mean } \pm \text { SD }\end{array}$} & \multirow{2}{*}{$\begin{array}{l}\text { No } \\
\text { Mean } \pm \text { SD }\end{array}$} & \\
\hline & & & & \\
\hline \multirow[t]{7}{*}{$\mathbf{R I}$} & Beginning & $23 \pm 3,92$ & $22,02 \pm 5,37$ & ${ }^{12} \mathbf{0 , 1 1 4}$ \\
\hline & 10. day & $20,77 \pm 5,4$ & $20,12 \pm 6,34$ & ${ }^{1 \mathrm{a}} \mathrm{O}, 438$ \\
\hline & 2. month & $19,94 \pm 5,28$ & $19,71 \pm 6,56$ & ${ }^{12} \mathbf{0 , 7 9 5}$ \\
\hline & $\mathbf{p}^{\mathbf{2 a}}$ & o,o0o* & o,o00* & \\
\hline & Beginning-10.day $p^{3 a}$ & $O, O O O^{*}$ & $O, O O O^{*}$ & \\
\hline & Beginning-2.month $p^{3 a}$ & $O, O O O^{*}$ & $O, O O O^{*}$ & \\
\hline & 10.day-2.month $p^{3 a}$ & 0,357 & 0,840 & \\
\hline \multirow[t]{7}{*}{ UV (meiyan) } & Beginning & $1,27 \pm 2,65(0,4)$ & $1,81 \pm 2,36(2)$ & ${ }^{1 b_{0}}, 065$ \\
\hline & 10. day & $2,01 \pm 2,26(2)$ & $2,83 \pm 2,59(2,7)$ & ${ }^{1 b_{0}} \mathbf{0 , 0 2 6 *}$ \\
\hline & 2. month & $2,66 \pm 2,33(2,7)$ & $3,21 \pm 2,64(3,2)$ & ${ }^{1 b} \mathbf{0 , 1 3 2}$ \\
\hline & $\mathbf{p}^{\mathbf{2 b}}$ & o,o0o* & o,o00* & \\
\hline & Beginning-1o.day $p^{3 a}$ & $O, O O O^{*}$ & $O, O O O^{*}$ & \\
\hline & Beginning-2.month $p^{3 a}$ & $O, O O O^{*}$ & $O, O O O^{*}$ & \\
\hline & 10.day-2.month $p^{3 a}$ & $O, O O O^{*}$ & $O, O O 1^{*}$ & \\
\hline \multirow[t]{7}{*}{ VT } & Beginning & $3,69 \pm 9,45$ & $4,82 \pm 9,94$ & ${ }^{12} 0,411$ \\
\hline & 10. day & $1,46 \pm 10,57$ & $2,6 \pm 12,61$ & ${ }^{12} \mathbf{0}, 497$ \\
\hline & 2. month & $-0,54 \pm 11,61$ & $0,63 \pm 14,08$ & ${ }^{1 a} 0,529$ \\
\hline & $\mathbf{p}^{\mathbf{2 a}}$ & $\mathbf{0 , \mathbf { O O 1 } ^ { * }}$ & o,o0o* & \\
\hline & Beginning-10.day $p^{3 a}$ & $0,017^{*}$ & $0,005^{*}$ & \\
\hline & Beginning-2.month $p^{3 a}$ & $O, O O O^{*}$ & $O, O O O^{*}$ & \\
\hline & 10.day-2.month $p^{3 a}$ & $0,011^{*}$ & $0,006^{*}$ & \\
\hline
\end{tabular}

${ }^{1 a}$ Student $t$ Test ${ }^{1 b}$ Mann Whitney U Test ${ }^{2 a}$ Analysis of Variance in Repetitive Measurements ${ }^{2 b}$ Friedman Test ${ }^{3 a}$ Bonferroni Test $\quad{ }^{3 b}$ Wilcoxon Sign Test $\quad{ }^{*} p<0.05$

As a result of the paired comparisons made to determine the period in which the difference originated, there was no significant difference in RI between the 1oth day and the 2nd month in either group. All other changes were statistically significant. 
When the patients are evaluated based on AO classification, there was no significant difference in the initial $10^{\text {th }}$ day and 2nd month radiological parameters in all three types (A, B or C). For type A3 patients, there was no significant difference in the RI change, the UV change between the 1oth day and the 2nd month, or the change between the initial 10th day and the 2nd month. All other changes were statistically significant (table 4).

Table 4. Evaluation of radiological parameters in AO type A fractures

\begin{tabular}{|c|c|c|c|c|}
\hline & & A2 & A3 & \multirow{2}{*}{$\mathbf{p}^{\mathbf{1}}$} \\
\hline & & $\operatorname{Mean} \pm$ SD & $\operatorname{Mean} \pm$ SD & \\
\hline \multirow[t]{7}{*}{$\mathbf{R} \dot{\mathbf{I}}$} & Beginning & $23,17 \pm 4,26$ & $23,11 \pm 5,46$ & $1 \mathbf{1 a}, 975$ \\
\hline & 10. day & $20,86 \pm 5,75$ & $24 \pm 6,28$ & $1 \mathrm{a} 0,162$ \\
\hline & 2. month & $20,46 \pm 5,37$ & $22,87 \pm 6,42$ & ${ }^{19} 0,288$ \\
\hline & $\mathbf{p}^{\mathbf{2 a}}$ & o,ooo* & 0,342 & \\
\hline & Beginning-10.day $p^{3 a}$ & $O, O O O^{*}$ & - & \\
\hline & Beginning-2.month $p^{3 a}$ & $O, O O O^{*}$ & - & \\
\hline & 10.day-2.month $p^{3 a}$ & 0,868 & - & \\
\hline \multirow[t]{7}{*}{ UV (median) } & Beginning & $1,51 \pm 2,18(1,6)$ & $1,92 \pm 2,56(1,6)$ & $\mathbf{b b}_{\mathbf{0}}, 713$ \\
\hline & 10. day & $2,36 \pm 2,25(2,5)$ & $3,13 \pm 2,12(3,1)$ & $\mathbf{1 b}_{\mathbf{0}}, \mathbf{3 2 7}$ \\
\hline & 2. month & $2,7 \pm 2,33(2,8)$ & $3,68 \pm 2,36(3,9)$ & ${ }^{1 b_{0}} \mathbf{0 , 2 9 9}$ \\
\hline & $\mathbf{p}^{\mathbf{2 b}}$ & $\mathbf{0 , 0 0 0 *}$ & $0,041^{*}$ & \\
\hline & Beginning-1o.day $p^{3 a}$ & $O, O O O^{*}$ & 0,116 & \\
\hline & Beginning-2.month $p^{3 a}$ & $O, O O O^{*}$ & $0,043^{*}$ & \\
\hline & 10.day-2.month $p^{3 a}$ & $0,004^{*}$ & 0,225 & \\
\hline \multirow[t]{7}{*}{ VT } & Beginning & $3,94 \pm 10,05$ & $5,86 \pm 10,22$ & $1 \mathrm{a} 0,622$ \\
\hline & 10. day & $1,32 \pm 11,75$ & $-1,63 \pm 9,78$ & 1a),516 \\
\hline & 2. month & $-0,69 \pm 13,09$ & $-4,59 \pm 8,87$ & ${ }^{1 a} 0,438$ \\
\hline & $\mathbf{p}^{\mathbf{2 a}}$ & o,000* & $\mathbf{0 , 0 0 7 *}$ & \\
\hline & Beginning-1o.day $p^{3 a}$ & $O, O O O^{*}$ & 0,271 & \\
\hline & Beginning-2.month $p^{3 a}$ & $O, O O O^{*}$ & 0,063 & \\
\hline & 10.day-2.month $p^{3 a}$ & $0,002 *$ & $0,027^{*}$ & \\
\hline
\end{tabular}

${ }^{1 a}$ Student $t$ Test ${ }^{1 b M a n n}$ Whitney $U$ Test ${ }^{2 a}$ Analysis of Variance in Repetitive Measurements ${ }^{2 b}$ Friedman Test ${ }^{3 a}$ Bonferroni Test $\quad{ }^{3 b}$ Wilcoxon Sign Test $\quad{ }^{*} p<0.05$

According to Lafontaine's stability criteria, of the 151 patients in the AO group A, 100 experienced instability; the change in radiological parameters was not statistically significant (Table 5). 
Table 5. Changes in radiological parameters according to La Fontaine's instability criteria

\begin{tabular}{|c|c|c|c|c|}
\hline & & Stable & Instable & \multirow{2}{*}{$\mathbf{p}$} \\
\hline & & Mean \pm SD & Mean \pm SD & \\
\hline \multirow[t]{3}{*}{$\mathbf{R I}$} & Beginning-10.day difference & $-2,31 \pm 4,79$ & $0,89 \pm 7,27$ & ${ }^{10,095}$ \\
\hline & Beginning-2.month difference & $-2,85 \pm 5,15$ & $-3,51 \pm 8,49$ & ${ }^{10,748}$ \\
\hline & 10.day-2.month difference & $-0,54 \pm 4,56$ & $-4,4 \pm 8,07$ & 10,254 \\
\hline \multirow[t]{3}{*}{ VT (medyan) } & Beginning-1o.day difference & $0,86 \pm 1,63(0,6)$ & $1,22 \pm 1,69(1,6)$ & ${ }^{2} 0,608$ \\
\hline & Beginning-2.month difference & $1,18 \pm 2(1,1)$ & $1,23 \pm 2,75(1,8)$ & ${ }^{2} \mathbf{o}, 758$ \\
\hline & 10.day-2.month difference & $0,32 \pm 1,7(0,3)$ & $0,02 \pm 1,76(0,2)$ & ${ }^{2} \mathbf{o}, 830$ \\
\hline \multirow[t]{3}{*}{$\mathbf{U V}$} & Beginning-1o.day difference & $-2,62 \pm 7,69$ & $-7,49 \pm 9,82$ & 10,108 \\
\hline & Beginning-2.month difference & $-4,62 \pm 9,6$ & $-10,44 \pm 8,88$ & 10,118 \\
\hline & 10.day-2.month difference & $-2 \pm 6,79$ & $-2,96 \pm 2,06$ & 10,712 \\
\hline
\end{tabular}

${ }^{1}$ Student $t$ Test ${ }^{2}$ Mann Whitney U Test

There was no significant difference in RI, UV, VT changes in type B1 patients, the RI changes in type B2, and VT changes in type $\mathrm{B}_{3}$ (table 6). As a result of the paired comparisons made to determine the period from which the difference originated, in the B3 group, there was no significant difference in the RI change between the initial 1oth day and the 2nd month of 10 days, and the UV change between the initial 1oth day; In the type B2 patients, there was no significant difference between the initial $10^{\text {th }}$ day and initial 2nd month. All other changes were statistically significant (Table 6).

Table 6. Evaluation of radiological parameters in AO type B fractures

\begin{tabular}{|c|c|c|c|c|c|}
\hline & & B1 & B2 & B3 & \multirow{2}{*}{$\mathbf{p}^{\mathbf{1}}$} \\
\hline & & $\operatorname{Mean} \pm$ SD & $\operatorname{Mean} \pm$ SD & $\operatorname{Mean} \pm$ SD & \\
\hline \multirow[t]{7}{*}{$\mathbf{R I}$} & Beginning & $23,57 \pm 3,19$ & $22,28 \pm 4,84$ & $21,01 \pm 4,68$ & ${ }^{12} 0,618$ \\
\hline & 10. day & $21,32 \pm 3,24$ & $21,13 \pm 5,73$ & $20,81 \pm 6,12$ & $\overline{12} \mathbf{0}, 986$ \\
\hline & 2. month & $20,5 \pm 7,21$ & $20,12 \pm 7,25$ & $17,36 \pm 4,67$ & ${ }^{1 \mathrm{a}} \mathrm{O}, 612$ \\
\hline & $\mathbf{p}^{\mathbf{2 a}}$ & $\mathbf{0 , 2 8 1}$ & $\mathbf{0 , 1 8 7}$ & $\mathbf{0 , 0 2 4}{ }^{*}$ & \\
\hline & Beginning-1o.day $p^{3 a}$ & - & - & $1, O O O$ & \\
\hline & $\begin{array}{l}\text { Beginning-2.month } \\
p^{3 a}\end{array}$ & - & - & $0,012^{*}$ & \\
\hline & 10.day-2.month $p^{3 a}$ & - & - & 0,111 & \\
\hline \multirow[t]{6}{*}{$\begin{array}{l}\mathrm{UV} \\
\text { (median) }\end{array}$} & Beginning & $\begin{array}{l}1,54 \pm 2,41 \\
(0,6)\end{array}$ & $1,08 \pm 2,33(0)$ & $0,7 \pm 2,15(0)$ & ${ }^{1 b} \mathbf{o}, 772$ \\
\hline & 1o. day & $\begin{array}{l}2,23 \pm 2,67 \\
(1,9)\end{array}$ & $\begin{array}{l}2,64 \pm 2,48 \\
(2,3)\end{array}$ & $1,23 \pm 1,91(1,6)$ & ${ }^{1 b} \mathbf{0}, 343$ \\
\hline & 2. month & $2,06 \pm 2,6(1,4)$ & $3,49 \pm 2,71(3,5)$ & $\begin{array}{l}3,41 \pm 2,74 \\
(3,8)\end{array}$ & ${ }^{1 b} \mathbf{0}, 525$ \\
\hline & $\mathbf{p}^{\mathbf{2 b}}$ & 0,143 & o,ooo* & o, o04* & \\
\hline & Beginning-10.day $p^{3 a}$ & - & $O, O O O^{*}$ & 0,249 & \\
\hline & $\begin{array}{l}\text { Beginning-2.month } \\
p^{3 a}\end{array}$ & - & $O, O O O^{*}$ & $0,018^{*}$ & \\
\hline
\end{tabular}




\begin{tabular}{|c|c|c|c|c|c|}
\hline & 10.day-2.month $p^{3 a}$ & - & $O, O O O^{*}$ & $0,027^{*}$ & \\
\hline \multirow[t]{7}{*}{ VT } & Beginning & $7,5 \pm 9,46$ & $3,94 \pm 9,92$ & $4,31 \pm 10,8$ & ${ }^{1 a} 0,726$ \\
\hline & 10. day & $5,8 \pm 10,61$ & $3,82 \pm 12,66$ & $3,53 \pm 14,21$ & ${ }^{1 a} \mathbf{0 , 9 3 4}$ \\
\hline & 2. month & $4,4 \pm 12,24$ & $-0,12 \pm 14,46$ & $1,06 \pm 15,16$ & ${ }^{12} \mathbf{0 , 7 7 5}$ \\
\hline & $\mathbf{p}^{\mathbf{2 a}}$ & $\mathbf{0 , 4 7 5}$ & $\mathbf{0 , 0 1 5 *}$ & 0,442 & \\
\hline & Beginning-1o.day $p^{3 a}$ & - & $1,0 O O$ & - & \\
\hline & $\begin{array}{l}\text { Beginning-2.month } \\
p^{3 a}\end{array}$ & - & 0,091 & - & \\
\hline & 10.day-2.month $p^{3 a}$ & - & $0,011^{*}$ & - & \\
\hline
\end{tabular}

${ }^{1 a}$ Student $t$ Test ${ }^{1 b}$ Mann Whitney $U$ Test ${ }^{2 a}$ Analysis of Variance in Repetitive Measurements ${ }^{2 b}$ Friedman Test ${ }^{3 a}$ Bonferroni Test $\quad{ }^{3 b}$ Wilcoxon Sign Test $\quad{ }^{*} p<0.05$

In type $\mathrm{C}$ patients, there was no significant difference between radiological parameter changes (Table 7).

Table 7. Evaluation of radiological parameters in AO type $\mathrm{C}$ fractures

\begin{tabular}{|c|c|c|c|c|c|}
\hline & & C1 & $\mathrm{C2}$ & C3 & \multirow{2}{*}{$\mathbf{p}^{1}$} \\
\hline & & $\operatorname{Mean} \pm$ SD & $\operatorname{Mean} \pm$ SD & $\operatorname{Mean} \pm$ SD & \\
\hline \multirow[t]{4}{*}{$\mathbf{R} \dot{\mathbf{I}}$} & Beginning & $18,75 \pm 6,1$ & $20,07 \pm 7,1$ & $16,9 \pm 7,77$ & ${ }^{1 a} \mathbf{0 , 7 0 7}$ \\
\hline & 10. day & $15,84 \pm 6,3$ & $16,95 \pm 7,25$ & $18,35 \pm 7,01$ & 1a), 757 \\
\hline & 2. month & $16,33 \pm 7,27$ & $16,41 \pm 6,99$ & $18,1 \pm 9,4$ & ${ }^{1 a} \mathbf{0 , 9 0 7}$ \\
\hline & $\mathbf{p}^{\mathbf{2 a}}$ & $\mathbf{0 , 0 8 0}$ & $\mathbf{0 , 1 0 4}$ & $\mathbf{0 , 8 7 2}$ & \\
\hline \multirow[t]{4}{*}{ UV (median) } & Beginning & $2,67 \pm 3,29(2,2)$ & $3,32 \pm 3,55(2,8)$ & $2,28 \pm 4,07(2,7)$ & ${ }^{1 b_{0}} \mathbf{0 , 9 0 1}$ \\
\hline & 10. day & $3,66 \pm 3,58(2,9)$ & $2,98 \pm 3,1(3,2)$ & $3,81 \pm 4,33(3,9)$ & ${ }^{1 b_{0}}, 944$ \\
\hline & 2. month & $4,02 \pm 3,14(4,2)$ & $3,4 \pm 3,16(3,8)$ & $4,82 \pm 3,18(3,8)$ & ${ }^{16} \mathbf{0 , 8 9 0}$ \\
\hline & $\mathbf{p}^{\mathbf{2 b}}$ & 0,092 & $\mathbf{0 , 3 3 2}$ & 0,368 & \\
\hline \multirow[t]{4}{*}{ VT } & Beginning & $5,56 \pm 9,27$ & $7,97 \pm 6,58$ & $5,48 \pm 10,68$ & ${ }^{1 a} 0,762$ \\
\hline & 10. day & $2,23 \pm 11,77$ & $10,35 \pm 14,27$ & $0,2 \pm 7,78$ & $1 a^{0,190}$ \\
\hline & 2. month & $4,3 \pm 14,9$ & $6,94 \pm 11,18$ & $-0,63 \pm 10,54$ & ${ }^{1 a} 0,642$ \\
\hline & $\mathbf{p}^{2 \mathbf{a}}$ & 0,214 & 0,434 & 0,249 & \\
\hline
\end{tabular}

${ }^{1 a}$ Student $t$ Test ${ }^{1 b}$ Mann Whitney $U$ Test ${ }^{2 a}$ Analysis of Variance in Repetitive Measurements ${ }^{2 b}$ Friedman Test ${ }^{3 a}$ Bonferroni Test $\quad{ }^{3 b}$ Wilcoxon Sign Test $\quad{ }^{*} p<0.05$

\section{Discussion}

The radiological parameters of the patients treated with cast applications with or without closed reduction due to the distal radius fractures were proned to change significantly in short term follow-ups. Further, the differences in these radiological parameters were not related to fracture type, gender, presence of accompanying ulnar fracture or age.

In treating distal radius fractures, closed reduction followed by cast immobilisation is accepted as a standard technique. Although there is a general consensus that the stability of the fracture determines the anatomical outcome of plaster immobilisation, the most appropriate tool for repairing distal radius fractures remains a topic of ongoing discussion ${ }^{21}$. Some recent orthopaedic 
texts recommend casting the distal radius fractures in neutral rotation or mild pronation, with mild flexion and ulnar deviation of the wrist ${ }^{25}$. A systematic study reviewed 37 randomised trials comparing different conservative treatment modalities ${ }^{11}$. The study concluded there was insufficient evidence to prefer any single conservative treatment modality over another, and therefore clinicians should use a recognised technique. When plaster immobilisation is not relied on to control alignment in the elderly with unstable osteoporotic fractures, the primary role of plaster is comfort and support. Therefore, the cast should be functional, relatively light and not interfere with forearm rotation or finger movements.

UV, VT and RI are the most widely used radiographic parameters for estimating functional results. However, there has been controversy regarding the relative importance of each factor affecting the functional outcome. Batra et al. determined the UV was the radiographic parameter showing the strongest correlation with the final functional results. Their study found that the loss of normal VT and RI was less associated with functional outcome ${ }^{26}$. Tsukazaki et al. showed that only VT is associated with functional results; they did not find a correlation between UV and loss of grip strength or range of motion ${ }^{27}$. In their comparative study, Cai et al. showed that UV is the most critical radiological parameter in determining the latest function and that the loss of radial length is directly related to poor function ${ }^{28}$. Radial shortening after DRF is among the primary factors affecting wrist joint function. When the radius is shortened, the load on the ulnar surface increases. This can significantly change the contact position and degree of stress, causing traumatic arthritis (caused by increased stress in the contact area), changes in conduction load, degenerative changes in the articular cartilage and instability of the wrist joint 29.

This study's findings emphasise the importance of accurately identifying the signs of instability such as dorsal angulation or rupture, the presence of accompanying ulnar fractures, and intraarticular involvement, especially in elderly osteoporotic patients. Lafontaine et al. showed that these risk factors are associated with loss of position despite immobility in a cast 23 . In this study, all patients over 65 years of age experienced worsening position, with deterioration independent of the instability criteria mentioned above.

In this study, patients were divided into two groups: under 75 and over 75 . In both groups, we found that UV, RI and VT radiological parameters worsened and significantly deteriorated in a plaster cast compared to the time of reduction. Although the World Health Organisation (WHO) grouped elderly patients as early-aged and late-aged, in our study, no significant difference was found between these age groups in the change in radiological parameters of DRFs.

We believe this is because osteoporosis, one of the most critical factors in these fractures and fracture reduction, affected both groups in the same way. We observed that this deterioration in radiological parameters was independent of the type of fracture. In addition, when the patients were evaluated for the presence of an accompanying ulnar fracture, gender and AO classification, we observed deterioration in UV, RI and VT parameters overtime under conservative treatment.

\section{Study Limitations}

The limitations of this study are as follows:

1. The study was conducted in a single centre with a retrospective research design.

2. The functional assessments were not evaluated.

3. The patients' bone density could not be evaluated to check the effect of osteoporosis on the treatment modality. We recommended a prospective multicentric cohort study involving 
bone density assessment and functional scores to produce more substantial clinical relevance.

\section{Conclusions}

It should always be kept in mind that the elderly patients who are treated conservatively due to the distal radius fracture may deteriorate the reduction quality of the fracture and that the accepted radiological parameters may worsen. In elderly patients, the deterioration in these parameters was independent of gender, the presence of ulnar fractures, and fracture classification.

\section{REFERENCES}

1. Nellans KW, Kowalski E, Chung KC. The epidemiology of distal radius fractures. Hand Clin. 2012. doi:10.1016/j.hcl.2012.02.001.

2. MacIntyre NJ, Dewan N. Epidemiology of distal radius fractures and factors predicting risk and prognosis. J Hand Ther. 2016. doi:10.1016/j.jht.2016.03.003.

3. Cummings SR, Blacks DM, Rubin SM. Lifetime risks of hip, colles', or vertebral fracture and coronary heart disease among white postmenopausasl women. Arch Intern Med. 1989. doi:10.1001/archinte.149.11.2445.

4. Arora R, Gabl M, Gschwentner M, Deml C, Krappinger D, Lutz M. A comparative study of clinical and radiologic outcomes of unstable colles type distal radius fractures in patients older than 70 years: Nonoperative treatment versus volar locking plating. $J$ Orthop Trauma. 2009. doi:10.1097/BOT.obo13e31819b24e9.

5. Arora R, Lutz M, Deml C, Krappinger D, Haug L, Gabl M. A prospective randomized trial comparing nonoperative treatment with volar locking plate fixation for displaced and unstable distal radial fractures in patients sixty-five years of age and older. J Bone Jt Surg Ser A. 2011. doi:10.2106/JBJS.J.01597.

6. Aktekin CN, Altay M, Gursoy Z, Aktekin LA, Ozturk AM, Tabak AY. Comparison between external fixation and cast treatment in the management of distal radius fractures in patients aged 65 years and older. J Hand Surg Am. 2010. doi:10.1016/j.jhsa.2010.01.028.

7. Wong TC, Chiu Y, Tsang WL, Leung WY, Yam SK, Yeung SH. Casting versus percutaneous pinning for extra-articular fractures of the distal radius in an elderly Chinese population: A prospective randomized controlled trial. J Hand Surg Eur Vol. 2010. doi:10.1177/1753193409339941.

8. Egol KA, Walsh M, Romo-Cardoso S, Dorsky S, Paksima N. Distal radial fractures in the elderly: Operative compared with nonoperative treatment. J Bone Jt Surg - Ser A. 2010. doi:10.2106/JBJS.I.00968.

9. Lutz K, Yeoh KM, Macdermid JC, Symonette C, Grewal R. Complications associated with operative versus nonsurgical treatment of distal radius fractures in patients aged 65 years and older. $J$ Hand Surg Am. 2014. doi:10.1016/j.jhsa.2014.04.018.

10. Chan YH, Foo TL, Yeo CJ, Chew WYC. Comparison between cast immobilization versus volar locking plate fixation of distal radius fractures in active elderly patients, the Asian perspective. Hand Surg. 2014. doi:10.1142/So21881041450004X. 
11. Handoll HH, Madhok R. Conservative interventions for treating distal radial fractures in adults. Cochrane Database Syst Rev. 2003. doi:10.1002/14651858.cdooo314.

12. Handoll HH, Madhok R. Surgical interventions for treating distal radial fractures in adults. Cochrane Database Syst Rev. 2009. doi:10.1002/14651858.cdo03209.pub2.

13. Chang HC, Tay SC, Chan BK, Low CO. Conservative treatment of redisplaced colles' fractures in elderly patients older than 60 years old - anatomical and functional outcome. Hand Surg. 2001. doi:10.1142/So218810401000606.

14. Anzarut A, Johnson JA, Rowe BH, Lambert RGW, Blitz S, Majumdar SR. Radiologic and patient-reported functional outcomes in an elderly cohort with conservatively treated distal radius fractures. $J$ Hand Surg Am. 2004. doi:10.1016/j.jhsa.2004.07.002.

15. Cooney WP, Linscheid RL, Dobyns JH. External pin fixation for unstable Colles' fractures. J Bone Jt Surg - Ser A. 1979. doi:10.2106/00004623-197961060-00006.

16. Knirk JL, Jupiter JB. Intra-articular fractures of the distal end of the radius in young adults. J Bone Jt Surg - Ser A. 1986. doi:10.2106/00004623-198668050-00003.

17. Ring D, Jupiter JB. Treatment of osteoporotic distal radius fractures. In: Osteoporosis International. 2005. doi:10.1007/s00198-004-1808-x.

18. Abe Y, Doi K, Kuwata N, Yamamoto H, Sunago K, Kawai S. Surgical options for distal radial fractures: Indications and limitations. Arch Orthop Trauma Surg. 1998. doi:10.1007/s004020050227.

19. Markiewitz AD, Gellman $\mathrm{H}$. Five-pin external fixation and early range of motion for distal radius fractures. Orthop Clin North Am. 2001. doi:10.1016/So030-5898(05)70253-4.

20. Rogachefsky RA, Lipson SR, Applegate B, Ouellette EA, Savenor AM, McAuliffe JA. Treatment of severely comminuted intra-articular fractures of the distal end of the radius by open reduction and combined internal and external fixation. J Bone Jt Surg - Ser A. 2001. doi:10.2106/00004623-200104000-00005.

21. Blakeney WG. Stabilization and treatment of colles' fractures in elderly patients. Clin Interv Aging. 2010. doi:10.2147/cia.s10042.

22. Dias JJ, Wray CC, Jones JM, Gregg PJ. The value of early mobilisation in the treatment of colles' fractures. J Bone Jt Surg - Ser B. 1987;69(3):463-467. doi:10.1302/0301620x.69b3.3584203.

23. Lafontaine M, Hardy D, Delince P. Stability assessment of distal radius fractures. Injury. 1989;20(4):208-210. doi:10.1016/0020-1383(89)90113-7.

24. Orimo H, Ito H, Suzuki T, Araki A, Hosoi T, Sawabe M. Reviewing the definition of “elderly." Geriatr Gerontol Int. 2006. doi:10.1111/j.1447-0594.2006.00341.x.

25. Leone J, Bhandari M, Adili A, McKenzie S, Moro JK, Dunlop RB. Predictors of early and late instability following conservative treatment of extra-articular distal radius fractures. Arch Orthop Trauma Surg. 2004. doi:10.1007/s00402-003-0597-6.

26. Batra S, Gupta A. The effect of fracture-related factors on the functional outcome at 1 year in distal radius fractures. Injury. 2002. doi:10.1016/So020-1383(01)00174-7. 
27. Tsukazaki T, Takagi K, Iwasaki K. Poor correlation between functional results and radiographic findings in colles' fracture. J Hand Surg Am. 1993. doi:10.1016/o2667681(93)90010-D.

28. Cai L, Zhu S, Du S, et al. The relationship between radiographic parameters and clinical outcome of distal radius fractures in elderly patients. Orthop Traumatol Surg Res. 2015. doi:10.1016/j.otsr.2015.04.011.

29. Wada T, Tsuji H, Iba K, Aoki M, Yamashita T. Simultaneous radial closing wedge and ulnar shortening osteotomy for distal radius malunion. Tech Hand Up Extrem Surg. 2005. doi:10.1097/01.bth.0000190817.89156.a2. 